\title{
Evaluation of membrane microfiltration fouling in landfill leachate treatment
}

\author{
Carine Pertile $^{1}$, Márcia Zanini ${ }^{2}$, Camila Baldasso ${ }^{3,}$
} Mara Zeni Andrade ${ }^{4}$, Isabel CristinaTessaro ${ }^{5}$

\author{
${ }^{1,5}$ Federal University of Rio Grande do Sul (UFRGS), Department of Chemical Engineering, Rua Luiz Englert, s/n. \\ Campus Central, CEP 90040-000, Porto Alegre, RS, Brasil. Tel.: +55 5133083277. \\ e-mail: carine.pertile@gmail.com, isabel@enq.ufrgs.br \\ 2,3,4 University of Caxias do Sul (UCS), Center of Exact Sciences and Technology (CCET), Rua Francisco Getúlio \\ Vargas n 1130, Bloco V, CEP 95070-560, Caxias do Sul, RS, Brasill. Tel.: +55 543218 - 2371. \\ e-mail: mzanini.marcia@gmail.com, cbaldasso@gmail.com,mzandrad@ucs.br
}

\begin{abstract}
The membrane separation capacity allows the retention of the remaining organic matter that could not be removed by the biological process, increasing the treatment efficiency. The aim of this study was to evaluate the microfiltration (MF) process in a tertiary treatment system for landfill leachate from the Rincão das Flores, Caxias do Sul/RS/Brazil. The microfiltration system of commercial hollow fiber membrane poly(etherimide) was tested in oder to promote leachate treatment. The tests carried out were leachate permeation, concentration factor, determination of fouling and obtention of the values of the resitance to the flux. The resistance due to fouling and flux decline were evaluated to determine the best operating conditions. The potential for fouling was $53 \%$ and was evaluated by comparing the pure water permeability before and after the leachate filtration. It was observed that the resistance due to fouling express $32 \%$ of the total resistance. The results showed that the MF process allows the elimination of up to $43 \%$ of the organic matter measured as chemical oxygen demand (COD) and $63 \%$ of that measured as biological oxygen demand $\left(\mathrm{BOD}_{5}\right)$.
\end{abstract}

Keywords: leachate; microfiltration; fouling; membrane resistance.

\section{INTRODUCTION}

In recent decades, the growing of waste production and leachate generation has been one of the most discussed topics that have focused on environmental preservation [1]. Barriers to innovations and possibilities to foment them have been discussed with reference to the leachate treatment [2]. Governmental intervention in terms of new or adapted policies and regulations might therefore be needed in order to create incentives to new technologies to leachate treatment.

Different processes have been used for the treatment of landfill leachate. The literature reports some processes that have been investigated for landfill leachate treatment: recirculation [3], electrochemical processes [4], biological processes (activated sludge, sequential batch reactor - RBS, long-term aeration, and anaerobic lagoon) [5,6,7], chemical precipitation [8], oxidation [9], sedimentation/ flotation [10], filtration and air stripping [11], the Fenton process [12], ultrafiltration (UF) [13], and reverse osmosis (RO) [14]. In most of the cases, it is necessary to combine two or more technologies to obtain a stream within discharge standards. After degradation, humic substances, such as compounds that have a high molecular weight, remain in the leachate. Due to the biological oxygen demand (BOD) reducing much faster than chemical oxygen demand (COD), the ratio of BOD/COD in stabilized leachate is less than 0.1. Therefore, if leachate is not treated properly, it can result in potential problems with ground water/surface water contamination [15]. The solutions for landfill leachate treatment typically use techniques already known of sewage treatment, as biological treatments. However, the application of these systems has generally found difficulties due the low biodegradability and high organic matter concentrations in the leachate. The values of these concentrations are dependent on the type and degree of solid waste stabilization, site hydrology, moisture content, seasonal weather variations, and age of the landfill and stage of the decomposition in the landfill. Therefore, due the large variability of characteristics of landfills leachate, there is no single technology for leachate treatment, the solution is to use combined systems, as biological systems and membrane separation processes. 
The microfiltration (MF) process has been used to improve the conventional leachate treatment because it removes high molecular mass compounds from old landfill leachates [16]. The membrane process enables the decrease of the operational costs, the reduction of the number of process steps whith greater efficiency in separation, hight quality of the final product and de-crease the environment impact, since this process requires no filtering aids such as diatomaceous earth and perlites. However, the major limitations in the membrane process are the concentration polarization, which is a boundary layer phenomenon that depends on the operating conditions and it is a reversible phenomenon, and membrane fouling, which is usually caused by specific physical and chemical interactions between the membrane and compounds in solution [17,18]. Membrane fouling causes, at constant transmembrane pressure, a significant decrease in the permeate flux over time, an alteration in retention during the filtration and, consequently, the decrease in the efficiency of the process.

Fouling occurs due to the increasing osmotic pressure and contaminants concentration on the membrane surface or within the structure of membranes that is not reversed by simply releasing the pressure or by backwashing [19]. Some foulants may be removed by physical or chemical cleaning but some fouling are irreversible. The fouling and concentration polarization induce additional resistance to transport through the membrane, which is dependent on the interactions between the membrane and the particulate, colloidal, and organic matter in the leachate. Membrane fouling is additionally influenced by several other factors such as feed solute molecular weight, feed concentration, and solute physical structure [20]. Thus, membrane fouling deteriorates membrane performance, increases operating cost and ultimately shortens membrane life.

As a modeling tool used in membrane process, the resistance-in-series model could be used to elucidate the process dynamics. Recently, many researchers have studied fouling resistance: LI et al. [21] obtained excellent protein-fouling-resistance performance from a sulfobetaine-grafted poly(vinylidene fluoride) (PVDF) hollow fiber membrane in the filtration solution, which contained inorganic electrolyte; AYDINER [22] investigated the relationships between flux decline and membrane fouling resistance during nanofiltration (NF), external fouling accounted for the most of all actual membrane fouling with a ratio between 90.0 and 97.7\%; ZHENG et al. [23] applied the resistance-in-series model to describe the permeation flux of the NF process. They found that the contribution of fouling resistance to the total permeation resistance (membrane and fouling resistance) was approximately $7.96 \%$ and $19.4 \%$ under the transmembrane pressure of 0.5 and 0.9 bar, respectively. This indicates that a higher transmembrane pressure leads to higher contributions of the fouling resistance to the total permeation resistance. PARASHURAM et al. [20] studied the contribution of fouling resistance (reversible and irreversible) of virgin and treated hollow fiber UF membranes. MORAVIA et al. [24] studied the resistance of each part that contributes to the total resistance of the MF process for leachate treatment. It was observed that membrane fouling occurs mainly due to pore blockage and consequently to cake formation. The resistance due to pore blockage was accounted for $24 \%$ of the total resistance, whereas $20 \%$ of the resistance was due to cake formation.

The importance in fouling control and process resistance are important to avoid the poor quality of permeate stream and low permeate flux. The aim of this research is to investigate the treatment of the landfill leachate using membrane technology, monitoring factors such as permeate flux, concentration polarization, process resistance, and fouling. The microfiltration system of commercial hollow fiber membrane poly(etherimide) was tested in oder to promote leachate treatment. The tests carried out were leachate permeation, concentration factor, determination of fouling and obtention of the values of the resitance to the flux.

\section{MATERIAL AND METHODS}

Leachate was provided by the Rincão das Flores landfill located in Caxias do Sul/RS, Brazil. It was collected from the sedimentation tank after activated sludge treatment and is characterized by a high COD and a high $\mathrm{BOD}_{5}$

Leachate was treated using a commercial MF poly (ether imide) membrane supplied by PAM Membranas Seletivas (Brazil) $(100 \mathrm{kDa})$; the hollow fiber module has an effective membrane area of $0.064 \mathrm{~m}^{2}$. It is important to note that before starting the experiment, the membrane was previously compacted, with change in transmembrane pressure of 0.5 to 1.4 bar, for three hours. The MF system used in this work is presented in Figure 1. The feed solution was pumped into the filtration module using a centrifuge pump. A prefilter with a nominal pore size of $1 \mu \mathrm{m}$ was used to retain suspended impurities that may damage the membrane. 


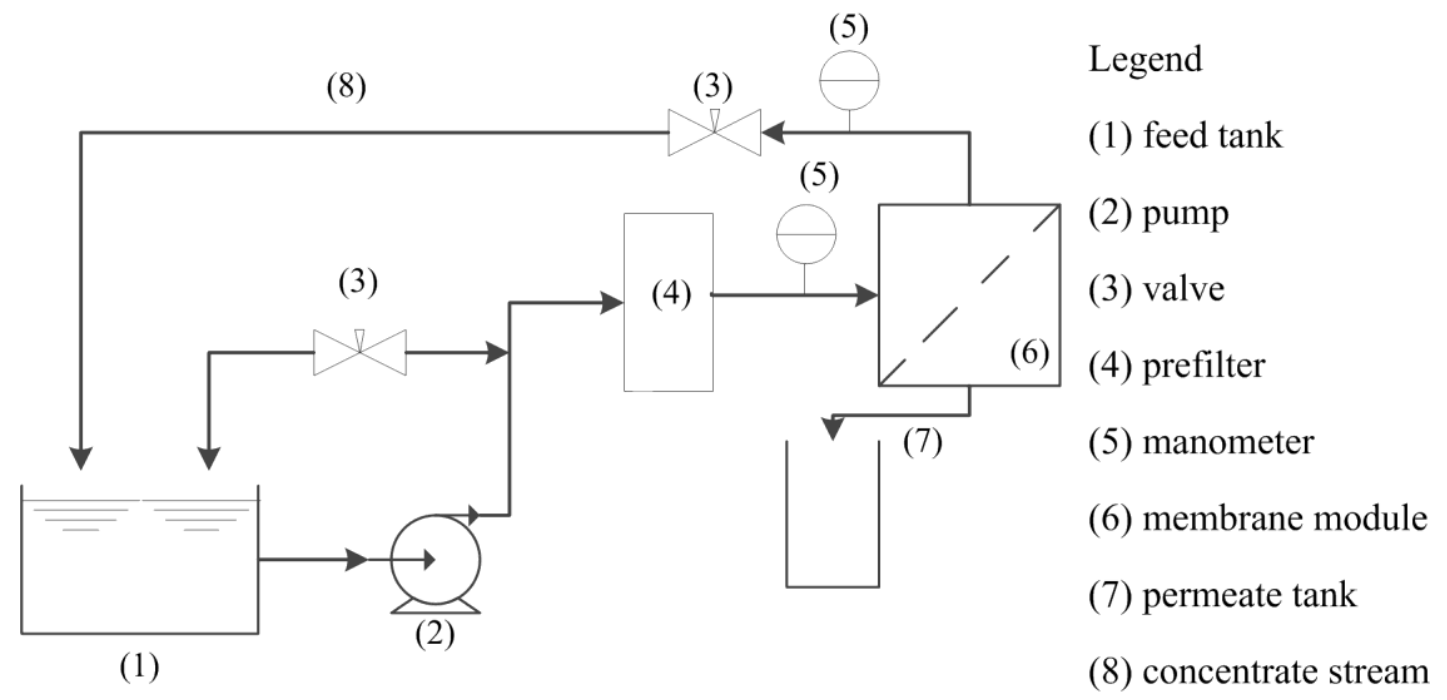

Figure 1: Schematic diagram of the MF system.

The feed solution crosses the module and is divided in two different streams, the permeate and the concentrate, which returns to the feed tank. Two manometers (0-14 bar) placed at the feed stream and at the concentrate stream display the transmembrane pressure, which is controlled by two valves.

The first experiment involved the determination of the leachate flux versus the filtration time at the following operating conditions: temperature of $25 \pm 3^{\circ} \mathrm{C}$, cross flux velocity of $8.9 \mathrm{~m} \mathrm{~s}^{-1}$, and transmembrane pressure of 0.5 bar. A total recycle mode was adopted for this test. The concentration factor $(\mathrm{CF})$ tests were carried out under the constant transmembrane pressure of $0.5 \mathrm{bar}$, the tests were performed in triplicate. The permeate solution was collected in a becker, whereas the retentate was circulated back to the feed tank, which concentrated the feed. The following Equation 1 determined the CF:

$$
C F=\frac{V_{i}}{V_{i}-V_{F}}
$$

where $V_{i}$ and $V_{F}$ are the initial volume of the feed solution and the generated permeate volume by the end of the experiment, respectively, both in $m L$.

To investigate the causes of the leachate permeate flux reduction during the MF process, the water permeate flux before and after the leachate experiments was measured. The fouling was estimated by comparing the pure water permeability before and after the leachate experiments according to the following Equation 2 [25]:

$$
\text { Fouling }(\%)=\left(1-\frac{D W P_{a}}{D W P_{b}}\right) \times 100
$$

where $D W P_{b}$ is the pure water permeability before the leachate experiments and $D W P_{a}$ is the pure water permeability after the leachate experiments, both in $L \mathrm{~m}^{-2} \mathrm{~h}^{-2} \mathrm{bar}^{-1}$.

The system resistances, due the different fouling mechanisms, were calculated using Darcy's law according to the following Equation 3:

$$
J=\frac{\Delta P}{\mu\left(R_{M}-R_{F}+R_{C}\right)}
$$

where $J$ is the leachate permeate flux $\left(m^{3} m^{-2} s^{-1}\right), \Delta P$ is transmembrane pressure $(k P a), \mu$ is the dynamic viscosity $\left(\right.$ Pa.s),$R_{M}$ is the membrane hydraulic resistance $\left(m^{-1}\right), R_{F}$ is the fouling resistance $\left(m^{-1}\right)$ and $R_{C}$ is a concentration polarization resistance $\left(m^{-1}\right)$.

The total resistance $\left(\mathrm{R}_{\mathrm{T}}\right)$, which is the sum of the filtration resistances, was calculated according to the resistance-in-series model. $\mathrm{R}_{\mathrm{T}}$ can be expressed as Equation 4 : 


$$
R_{T}=R_{M}+R_{F}+R_{C}
$$

$\mathrm{R}_{\mathrm{M}}$ is caused by geometric factors such as pore size and pore distribution, the membrane thickness, and hydrophilic and hydrophobic characteristics. For new membranes, the $\mathrm{R}_{\mathrm{M}}$ value varies according to compaction. Thus, $\mathrm{R}_{\mathrm{M}}$ was determined by filtering distilled water through the newly compacted membrane (with change in transmembrane pressure of 0.5 to 1.4 bar, for three hours) using the following Equation 5:

$$
R_{M}=\frac{\Delta P}{\mu_{w} J_{w}}
$$

where the subscript ' $w$ ' refers to water properties.

$\mathrm{R}_{\mathrm{F}}$ is the resistance due to pore adsorption, pore blocking, and cake formation. It was calculated by measuring the water flux after the leachate experiment $\left(\mathrm{J}_{\mathrm{W}}{ }^{\prime}\right)$ as follows Equation 6 :

$$
R_{F}=\frac{\Delta P}{\mu_{w} J_{w}^{\prime}}-R_{M}
$$

Finally, $\mathrm{R}_{\mathrm{C}}$ was calculated by subtracting all other resistances to the $\mathrm{R}_{\mathrm{T}}$ (Equation 7):

$$
R_{C}=R_{T}-R_{M}-R_{F}
$$

After each experiment, the membrane was flushed with distilled water and submitted to cleaning, both alkaline $(\mathrm{NaOH})$ and acid (citric acid). First, the alkaline solution was dosed until $\mathrm{pH} 10$ to remove organic deposits. Then, the system was washed with distilled water, and the acid solution was added to acidify it to $\mathrm{pH}$ 4 to remove inorganic matter. The effectiveness of cleaning was confirmed by measuring the increase of the permeate water flux. The tests were performed in triplicate.

\section{RESULTS AND DISCUSSION}

Therefore, membrane process for leachate treatment has been considered to have some advantages over the conventional process. Physical-chemical and biological treatments are typically used to reduce the concentration of the pollutants in the leachate. However, these kinds of methods do not achieve the pollutant limits established in law and not produce recycled water for other process. Membrane technologies provide important solution in environmental fields such as pollution and water reuse, recycling valuable components from the waste streams [26]. The results of $\mathrm{BOD}_{5}$ and $\mathrm{COD}$ of feed leachate (collected from the sedimentation tank after activated sludge treatment), permeate and concentration streams from the MF process are given in Table 1.

Table $1-\mathrm{BOD}_{5}$ and COD mean values of feed leachate, permeate and concentration streams from the MF process.

\begin{tabular}{l|l|l|l|c|c}
\hline Parameter & Units & Feed & Permeate & $\begin{array}{c}\text { \% Removed in relation } \\
\text { with the permeate }\end{array}$ & Regulatory Determination \\
\hline $\mathrm{BOD}_{5}$ & $\mathrm{mgL}^{-1}$ & 651 & 238 & 63 & 180 \\
\hline $\mathrm{COD}$ & $\mathrm{mgL}^{-1}$ & 1182 & 678 & 43 & 400 \\
\hline
\end{tabular}

It was found that MF was not sufficient for inclusion in the regulatory standards for effluent discharge according to Resolução CONSEMA N ${ }^{\circ}$ 128, December 7, 2006 (Regulatory Determination). However, the removal of this pollutant was relevant. The MF process allows the elimination organic matter in the percentage represented in Table 1, this means that there is organic matter present in solution with a molecular weight greater than $100 \mathrm{kDa}$ that demands oxygen, and part of it can be removed by MF.

LU et al. [26] studied a wastewater reclamation system for printing and dyeing wastewater treatment from a textile factory using biological treatment process and membrane filtration. This effluent show similar characteristics to the leachate like high COD and BOD. The average COD and turbidity removal efficiencies, observed by the authors, were $91 \%$ and $90.9 \%$, respectively. The results obtained in this article are considered satisfactory values.

However, microfiltration process show some disadvantage, significant loss of performance with respect to flux and often selectivity attributed to fouling and process resistance. This limitation shortens the 
membrane life due to chemical cleaning. To minimize this, mechanical, chemical and thermal stabilities are important characteristics that should be considered in choice of membrane. Further, important characteristics for high performance like high flux, selectivity and low fouling should be considered. To improve membrane process, permeate flux and fouling should be controlled. Figure 2 shows the permeate leachate flux and water flux behavior as a function of time. The permeate leachate flux decreased to $20 \mathrm{~L} \mathrm{~m}^{-2} \mathrm{~h}^{-1}$ after 102 minutes of the filtration process, which represents a permeate flux reduction of approximately $30 \%$. The flux decline is mainly due the deposition and absorption of foulants on the membrane. This provides evidence for the existence of strong membrane-solution interactions.

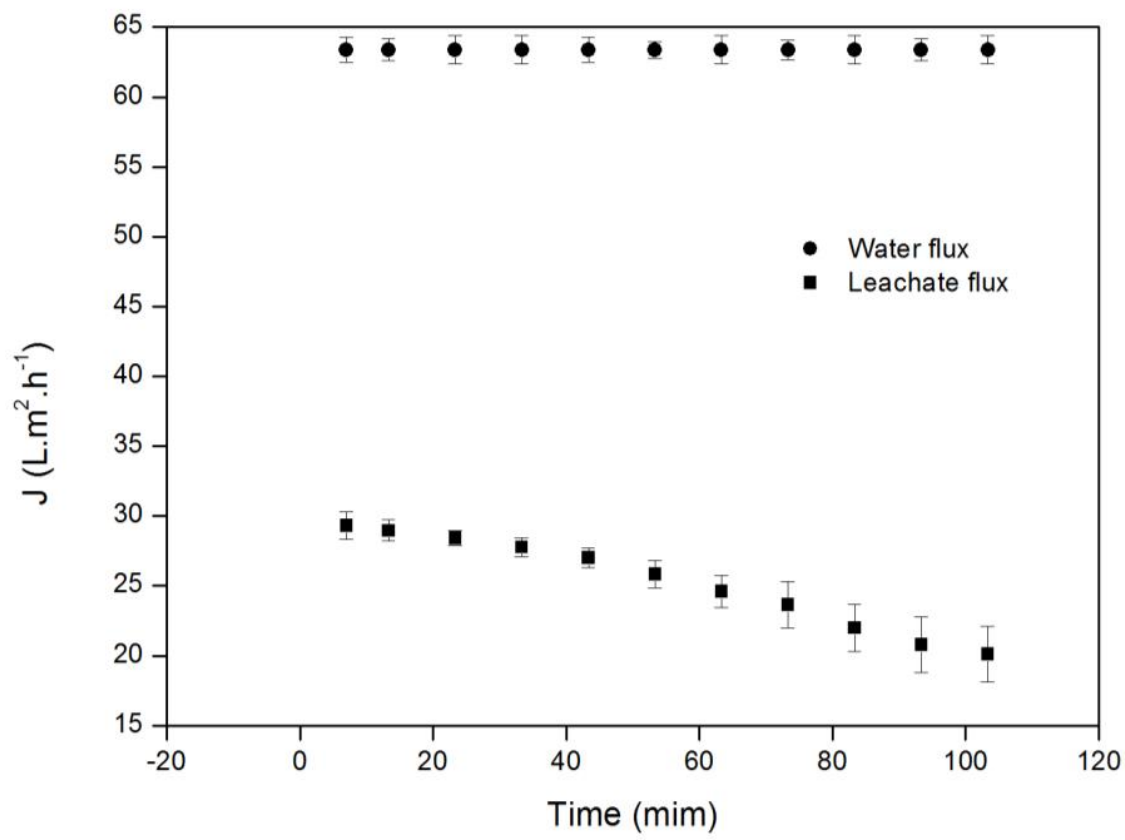

Figure 2: Permeate flux as a function of filtration time for the leachate and water flux for three replicates at $25 \pm 3^{\circ} \mathrm{C}$ and a transmembrane pressure of 0.5 bar.

The data presented in Figure 2 confirm what several authors have already observed. PI et al. [11] studied leachate treatment with a tubular membrane $(3 \mathrm{kDa})$ at $\triangle \mathrm{P} 0.7 \mathrm{MPa}$ and observed a permeate flux reduction of $23.3 \%$ in the first 54 minutes of operation, which was further reduced to values close to zero after 72 minutes of the experiment. According to these authors, one of the adverse effects of membrane fouling is permeate flux reduction $[11,27]$.

INCE et al. [28] suggested that a membrane with a higher flux rate becomes fouled faster, indicating the occurrence of fouling. The fouling of the membrane was caused by the high molecular weight cut-off (MWCO) values, which indicate easy adsorption of large molecular weight molecules, such as fulvic and humic acid present in the feed on to the membrane surface. The higher surface roughness and hydrophilic characteristics of the membrane could make the fouling worse. According to PARASHURAM et al. [20], the permeate flux is also influenced by factors such as solute molecular weight, feed concentration, and the physical structure of the membrane (spherical or linear). AYDINER [22] emphasize that the flux decrease is associated not only with the feed concentration but also with the pore membrane blockage.

To evaluate the effect of the feed solution concentration on the leachate permeate flux, the concentration factor $(\mathrm{CF})$ was determined. Figure 3 presents the leachate permeate flux as a function of the feed solution concentration factor for three replicates. The permeate flux decreases with increasing feed concentration. At a CF value of 2.5 , an average reduction of $30 \%$ of the permeate flux was observed. The higher concentration of solute near the surface of the membrane, occurs due to the increase feed concentration or the denser concentration polarization layer provides the reduction of permeate flux [29]. 


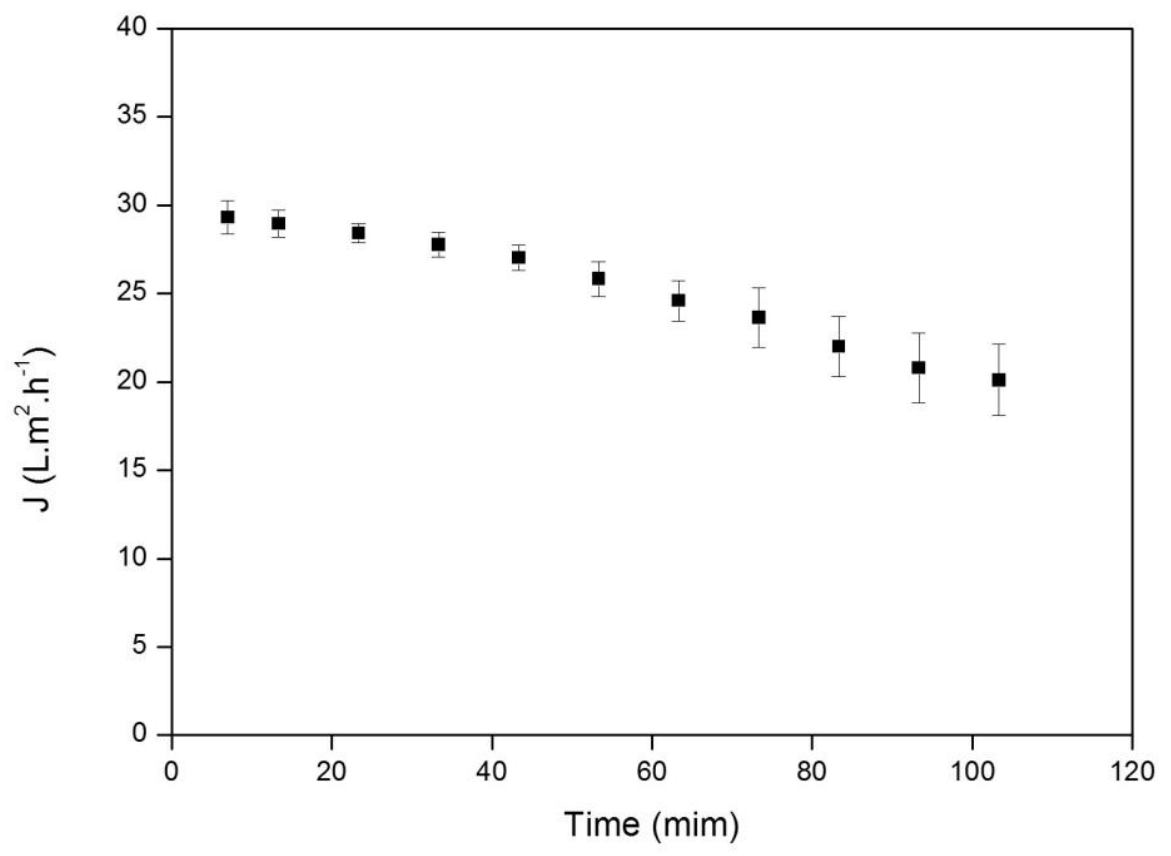

Figure 3: Leachate permeate flux as a function of the feed solution concentration factor for three replicates at $25 \pm 3^{\circ} \mathrm{C}$ and a transmembrane pressure of 0.5 bar.

According to ŠÍR et al. [30], the decrease of the permeate flux was caused by an increase of the osmotic pressure of the solution and the high accumulation of solute molecules in the polarized concentration layer, which increased the resistance to permeation. The concentration polarization occurs due to the seletivity of the membrane, allows the passage of some solutes, occurring accumulation of rejected solutes at membrane surface, forming a surface layer that will provide significant resistance to the separation process [31].

Figure 4 shows the distilled water permeate flux for the membrane, fouled membrane, and membrane after chemical cleaning and the leachate permeate flux as a function of the transmembrane pressure.

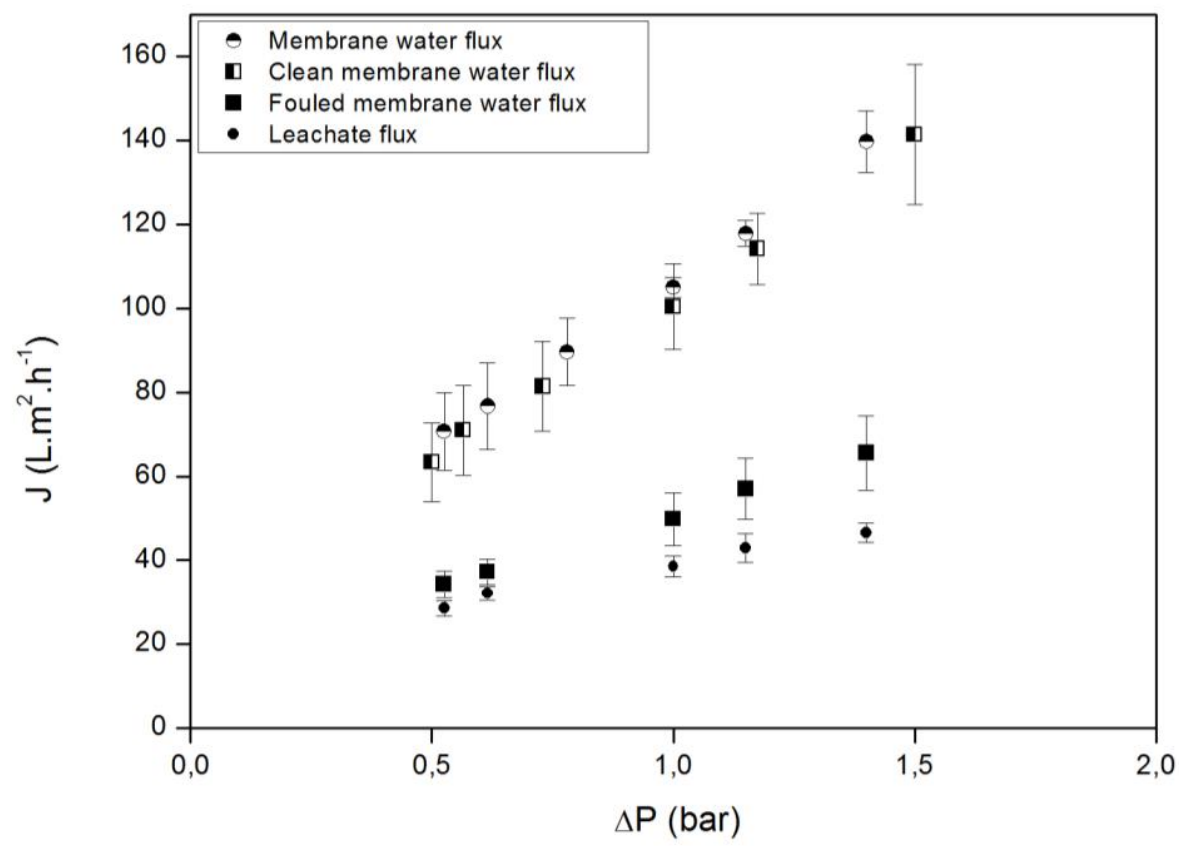

Figure 4: Distilled water permeate fluxes and leachate permeate flux as a function of transmembrane pressure. 
The experimental results revealed that increasing the operating pressures resulted in an increase in the permeate flux for both pure water and leachate. The leachate flux was lower than the water fluxes. This is explained by the fouling and concentration polarization that occur during the MF process

The potential for fouling was $53 \%$ and was evaluated by comparing the pure water permeability before and after the leachate filtration [25]. The difference between the new membrane water flux and the fouled membrane water flux, shown in Figure 4, is exclusively due to fouling because there is no interference from concentration polarization, as this phenomenon occurs only during operation of the system. The leachate experiments occurred at $25 \pm 3^{\circ} \mathrm{C}$ and a transmembrane pressure of 0.5 bar. The pure water permeability before and after filtration was $95.89 \mathrm{~L} \mathrm{~m}^{-2} \mathrm{~h}^{-1}$ bar $^{-1}$ and $45.18 \mathrm{~L} \mathrm{~m}^{-2} \mathrm{~h}^{-1} \mathrm{bar}^{-1}$, respectively.

The water flux after chemical cleaning was measured to evaluate the existence of irreversible fouling. The result shown in Figure 4 confirms the efficiency of chemical cleaning for removing organic components from the membrane.

The $\mathrm{R}_{\mathrm{M}}, \mathrm{R}_{\mathrm{F}}, \mathrm{R}_{\mathrm{C}}$ and $\mathrm{R}_{\mathrm{T}}$ values are shown in Figure 5 .

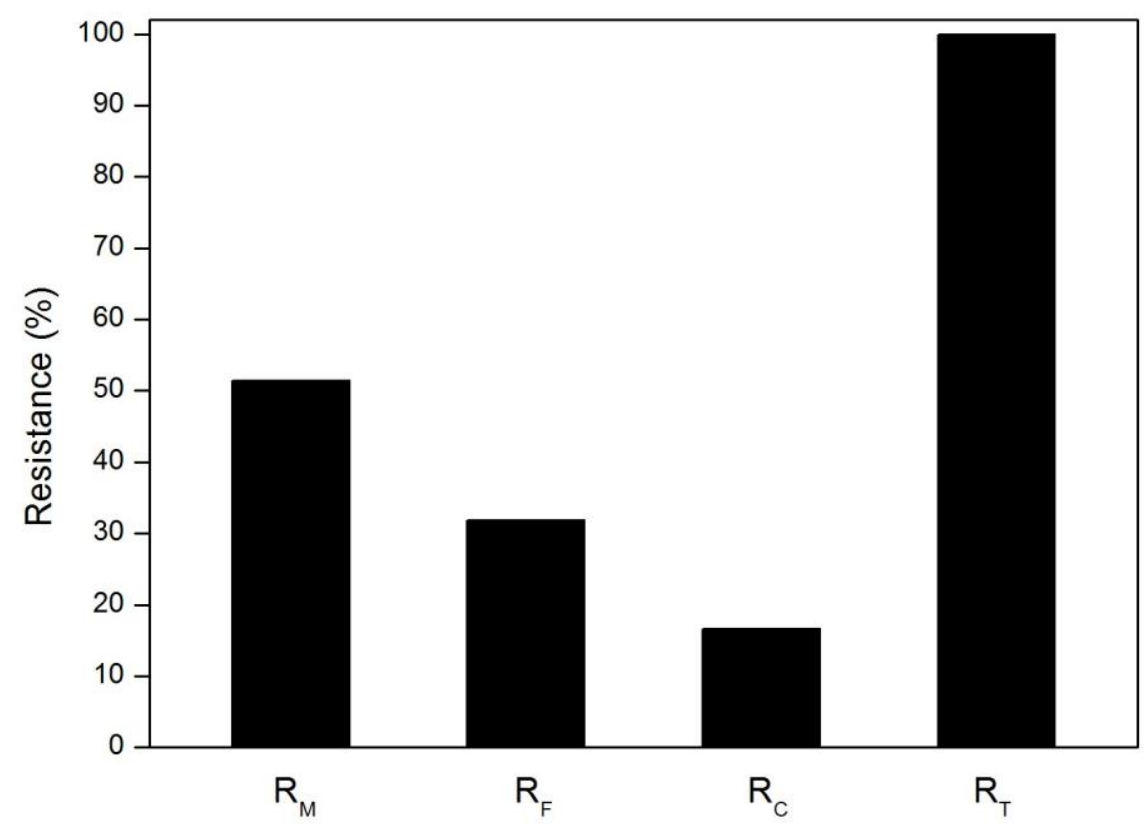

Figure 5: $R_{M}, R_{F}, R_{C}$, and $R_{T}$ values in $M F$ at $25 \pm 3^{\circ} \mathrm{C}$ and a transmembrane pressure of 0.5 bar.

It was observed that the resistance due to fouling $\left(\mathrm{R}_{\mathrm{F}}\right)$ accounted for $32 \%$ of the total resistance $\left(\mathrm{R}_{\mathrm{T}}\right)$, whereas $17 \%$ of the resistance was due to concentration polarization $\left(\mathrm{R}_{\mathrm{C}}\right)$. Nevertheless, the most significant resistance was the intrinsic membrane resistance $\left(3.30 \times 10^{12} \mathrm{~m}^{-1}\right)$, which represented more than $50 \%$ of the total.

MORAVIA et al. [24] present similar results in tests with MF process for landfill leachate treatment, pre-treated by Fenton process. The authors found that the resistance of the membrane contributed for $50 \%$ of the total resistance when the system operated at 0.25 bar. For both, $R_{F}$ and $R_{C}$ increased with increased operating pressures. It was observed that the recoverable fouling resistance, $\mathrm{R}_{\mathrm{C}}$, decreased from $3.04 \times 10^{12} \mathrm{~m}^{-1}$ to $1.07 \times 10^{12} \mathrm{~m}^{-1}$ with decreased operating pressures from 1.4 bar to 0.5 bar. System cleaning could effectively remove organic components concentration and adsorbed organic components from the membrane surface and/or pores. Decreased operating pressures ranging from 1.4 bar to 0.5 bar, decrease $\mathrm{R}_{\mathrm{F}}$ from $4.16 \mathrm{x}$ $10^{12} \mathrm{~m}^{-1}$ to $2.05 \times 10^{12} \mathrm{~m}^{-1}$. The results corresponded to decrease in permeate flux with decrease transmembrane pressure. This indicated a decreased in membrane permeability, thus increased the membrane hydraulic resistance. WU et al. [32] studied the fouling on the polysulphone UF membrane with a solution of similar characteristics of leachate and observed that the greatest fouling occurred at the highest applied pressure of $0.8 \mathrm{MPa}$ with fouling to $85.8 \%$, followed by applied pressure of $0.2 \mathrm{MPa}$ with fouling to $75.1 \%$. The authors attributed the high percentages of fouling, even when the operation occurred at lower pressures, to the hydrophobicity of the membrane, which has a significant tendency to adsorption on the surface, which can lead to 
the formation of a fouling layer.

$R_{F}$ and $R_{C}$ generally increase with time, resulting in a decline in the permeate flux. This behavior can be explained by the membrane pore obstruction that occurs as the result of the particles present in the feed, whose colloidal nature favors their own deposition in the membrane pores [24]. The increase of $R_{C}$ and $R_{F}$ is related to the increase of solute near the membrane surface due to the increase in pressure. An alternative to reduce the $\mathrm{R}_{\mathrm{C}}$ and $\mathrm{R}_{\mathrm{F}}$ is increasing the cross-flow velocity. The higher the cross-flow rate, the higher the turbulence near the membrane surface, which reduces the thickness of the polarized layer and increases the flux through the membrane [24].

\section{CONCLUSIONS}

A difference between the leachate and distilled water fluxes was observed. This difference is most likely related to membrane fouling, as verified in the resistance and fouling analysis. It was observed that the resistance due to fouling express $32 \%$ of the total resistance and the potential for fouling was $53 \%$. The main resistance in this process was found to be the intrinsic membrane resistance, followed by the fouling resistance, with the concentration polarization resistance the least expressive.

The MF system proved to be technically feasible associated with operational advantages such as simplicity of operation and efficient chemical cleaning. Despite organic matter concentration above the limits according to current legislation (Resolução CONSEMA $N^{\circ} 128$, December 7, 2006), the removal of this pollutant was relevant. and was evaluated by comparing the pure water permeability before and after the leachate filtration. The results showed the reduction of up to $43 \%$ of the organic matter measured as COD and $63 \%$ of that measured as $\mathrm{BOD}_{5}$ by MF process, in operation at $25 \pm 3^{\circ} \mathrm{C}$ and a transmembrane pressure of 0.5 bar. Moreover, the MF process revealed a high flux and a low total resistance. Thus, MF system combined to the biological system in the existing landfill proved a potential alternative for landfill leachate treatment characterized as a superior solution for fast, compact and efficient removal of pollutant.

The results provide subsidies to a better understanding of the phenomena that occur during MF, after biological treatment, that allow a better proposal configuration and operational procedures of an optimized system for this purpose. The adoption of technical and operational strategies and innovation in the use of new technologies contributed to the efficiency of the treatment.

\section{BIBLIOGRAPHY}

[1] FRÄNDEGÅRD, P., KROOK, J., SVENSSON, N., et al., "A Novel Approach for Environmental Evaluation of Landfill Mining”, Journal of Cleaner Production, v. 55, pp. 24-34, 2013.

[2] KROZER, Y., HOPHMAYER-TOKICH, S., MEERENDONK, H.V, et al., "Innovations in the Water Chain - Experiences in The Netherlands", Journal of Cleaner Production, v.18, n. 5, pp. 439-446, 2010.

[3] REINHART, D.R., AL-YOUSFI, A. B. "The Impact of Leachate Recirculation on Municipal Solid Waste Landfill Operating Characteristics", Waste Management \& Research, v. 14, pp. 337-346, 1996.

[4] CHIANG, L.C., CHANG, J.E., WEN, T.C. "Indirect Oxidation Effect in Electrochemical Oxidation Treatment of Landfill Leachate", Water Research, v. 29, n. 2, pp. 671-678, 1995.

[5] LI, H., ZHOU, S., SUN, Y, et al., "Advanced Treatment of Landfill Leachate by a New Combination Process in a Full-Scale Plant.” Journal of Hazardous Materials, v. 172, n. 1, pp. 408-415, 2009.

[6] MEHMOOD, M.K., ADETUTU, E., NEDWELL, D.B., et al., "In Situ Microbial Treatment of Landfill Leachate Using Aerated Lagoons", Bioresource Technology, v. 100, n.10, pp. 2741-2744, 2009.

[7] SPAGNI, A., MARSILI-LIBELLI, S. "Nitrogen Removal via Nitrite in a Sequencing Batch Reactor Treating Sanitary Landfill Leachate", Bioresource Technology, v. 100, n. 2, pp. 609-614, 2009.

[8] ZHANG, T., DING, L., REN, H., "Pretreatment of Ammonium Removal from Landfill Leachate by Chemical Precipitation", Journal of Hazardous Materials, v. 166, n. 2-3, pp. 911-915, 2009.

[9] TIZAOUI, C., BOUSELMI, L., MANSOURI, L., et al., "Landfill Leachate Treatment with Ozone and Ozone/hydrogen Peroxide Systems", Journal of Hazardous Materials, v. 140, n. 1-2, pp. 316-324, 2007.

[10] GUIGUE, J., MATHIEU, O., LÉVÊQUE, J., et al., "Dynamics of Copper and Zinc Sedimentation in a Lagooning System Receiving Landfill Leachate", Waste Management, v. 33, n. 11, pp. 2287-2295, 2013.

[11] PI, K.W., LI, Z., WAN, D.J., et al., "Pretreatment of Municipal Landfill Leachate by a Combined Process", Process Safety and Environmental Protection, v. 87, n. 3, pp. 191-196, 2009. 
[12] KOCHANY, J., LIPCZYNSKA-KOCHANY, E., "Utilization of Landfill Leachate Parameters for Pretreatment by Fenton Reaction and Struvite Precipitation-A Comparative Study", Journal of Hazardous Materials, v. 166, n. 1, pp. 248-254, 2009.

[13] XU, Y.D., YUE, D.B., ZHU, Y., et al., "Fractionation of Dissolved Organic Matter in Mature Landfill Leachate and Its Recycling by Ultrafiltration and Evaporation Combined Processes", Chemosphere, v. 64, n. 6, pp. 903-911, 2006.

[14] RENOU, S., GIVAUDAN, J.G., POULAIN, S., et al., "Landfill Leachate Treatment: Review and Opportunity", Journal of Hazardous Materials, v. 150, n. 3, pp. 468-493, 2008.

[15] RAFIZUL, I.M., ALAMGIR, M. "Characterization and Tropical Seasonal Variation of Leachate: Results from Landfill Lysimeter Studied”, Waste Management, v. 32, n. 11, pp. 2080-2095, 2012.

[16] SILVA, A.C., DEZOTTI, M., SANT'ANNA, G.L., "Treatment and Detoxification of a Sanitary Landfill Leachate." Chemosphere, v. 55, n. 2, 207-214, 2004.

[17] NAKAMURA, K., ORIME, T., MATSUMOTO, K., "Response of Zeta Potential to Cake Formation and Pore Blocking during the Microfiltration of Latex Particles", Journal of Membrane Science, v. 401-402, pp. 274-281, 2012.

[18] XIONG, B., ZYDNEY, A.L., KUMAR, M., "Fouling of Microfiltration Membranes by Flowback and Produced Waters from the Marcellus Shale Gas Play”, Water Research, v. 99, pp. 162-170, 2016.

[19] SIOUTOPOULOS, D.C., KARABELAS, A.J., "Correlation of organic fouling resistances in RO and UF membrane filtration under constant flux and constant pressure", Journal of Membrane Science, v. 407-408, pp. 34-46, 2012.

[20] PARASHURAM, K., MAURYA, S.K., RANA, H.H., et al., "Tailoring the Molecular Weight Cut off Values of Polyacrylonitrile Based Hollow Fibre Ultrafiltration Membranes with Improved Fouling Resistance by Chemical Modification”, Journal of Membrane Science, v. 425-426, pp. 251-261, 2013.

[21] LI, Q., BI, Q.Y., LIU, T.Y., et al., "Resistance to Protein and Oil Fouling of Sulfobetaine-Grafted Poly(vinylidene Fluoride) Hollow Fiber Membrane and the Electrolyte-Responsive Behavior in NaCl Solution", Applied Surface Science, v. 258, n. 19, pp. 7480-7489, 2012

[22] AYDINER, C. "A Novel Approach Based on Distinction of Actual and Pseudo Resistances in Membrane Fouling: 'Pseudo Resistance' concept and Its Implementation in Nanofiltration of Single Solutions", Journal of Membrane Science, v. 361, n. 1-2, pp. 96-112, 2010.

[23] ZHENG, Y., YU, S., SHUAI, S., et al., "Color removal and COD reduction of biologically treated textile effluent through submerged filtration using hollow fiber nanofiltration membrane", Desalination, v. 314, pp. 89-95, 2013.

[24] MORAVIA, W.G., AMARAL, M.C.S., LANGE, L.C., "Evaluation of Landfill Leachate Treatment by Advanced Oxidative Process by Fenton's Reagent Combined with Membrane Separation System ", Waste Management, v. 33, n. 1, pp. 89-101, 2013.

[25] MÄNTTÄRI, M., VIITIKKO, K., NYSTRÖM, M., "Nanofiltration of Biologically Treated Effluents from the Pulp and Paper Industry", Journal of Membrane Science, v. 272, n. 1-2, 152-160, 2006.

[26] LU, X., YANG, B., CHEN, J., et al., "Treatment of Wastewater Containing Azo Dye Reactive Brilliant Red X-3B Using Sequential Ozonation and Upflow Biological Aerated Filter Process", Journal of Hazardous Materials, v. 161, n. 1, pp. 241-245, 2009.

[27] MATTARAJ, S., PHIMPHA, W., HONGTHONG, P., et al., "Effect of operating conditions and solution chemistry on model parameters in crossflow reverse osmosis of natural organic matter", Desalination, v. 253, pp. 38-45, 2010.

[28] INCE, M., SENTURK, E., ONKAL ENGIN, G., et al., "Further Treatment of Landfill Leachate by Nanofiltration and Microfiltration-PAC Hybrid Process", Desalination, v. 255, n. 1-3, pp. 52-60, 2010.

[29] LEE, S.J., DILAVER, M., PARK, P.K., et al., "Comparative analysis of fouling characteristics of ceramic and polymeric microfiltration membranes using filtration models", Journal of Membrane Science, v. 432, 97-105, 2013.

[30] ŠÍR, M., PODHOLA, M., PATOČKA, T., et al., "The Effect of Humic Acids on the Reverse Osmosis Treatment of Hazardous Landfill Leachate", Journal of Hazardous Materials, v. 207-208, pp. 86-90, 2012.

[31] RAYESS, Y. E., ALBASI, C., BACCHIN, P., et al., "Analysis of membrane fouling during cross-flow microfiltration of wine”, Innovative Food Science \& Emerging Technologies, v.16, pp. 398-408 2012. 
[32] WU, T.Y., MOHAMMAD, A.W., JAHIM, J.M., et al., "Palm Oil Mill Effluent (POME) Treatment and Bioresources Recovery Using Ultrafiltration Membrane: Effect of Pressure on Membrane Fouling", Biochemical Engineering Journal, v. 35, n. 3, pp. 309-317, 2007. 